PRR

6,2

Received 10 July 2020 Revised 30 October 2020 Accepted 2 November 2020

\section{Discovering the linear relationship of service quality, satisfaction, attitude and loyalty for banks in Albaha, Saudi Arabia}

\author{
Adil Zia
}

Department of Marketing, AlBaha University, Al Baha, Saudi Arabia

\begin{abstract}
Purpose - This study aims to examine the factors that lead to loyalty in bank customers. It establishes a relationship of service quality $(\mathrm{SQ})$ with satisfaction and attitude that leads to customer loyalty. The impact of SQ along with satisfaction and attitude on customer loyalty is explored.

Design/methodology/approach - Primary data was collected from 1,097 customers of the banking service. Structural equation modelling (SEM) and multiple regression analyses was used to analyse the data. The adaption of multiple regression and SEM for the analysis authenticates the similar findings in both the methods of analysis.

Findings - All the factors contribute to the formation of SQ. There exists a linear relationship of SQ, satisfaction and attitude in the formation of customer loyalty.

Research limitations/implications - Sample can be more diverse and collected from different cities as well. Similar studies are possible for diverse demographic groups such as gender, age, education and others.

Practical implications - The results of this study have significant implications for understanding customer loyalty for banks of Saudi Arabia.

Originality/value - This research attempts to explore the factors responsible for the SQ in banks of Saudi Arabia so as to establish a relationship between SQ, satisfaction, attitude and loyalty.
\end{abstract}

Keywords Service quality, Satisfaction, Customer loyalty, Attitude, SEM, Multiple regression

Paper type Research paper

\section{Introduction}

The Saudi banking sector is one of the world's largest and fastest-growing banking sectors. There are 24 commercial banks out of which 12 are domestic and 12 are foreign banks (SAMA, 2020). The fast-growing Saudi economy has positively influenced the Saudi banks, as more and more people need banking services for both commercial as well as personal use. Although, it has been observed in various research studies that the Saudi banking sector is not market-oriented and does not consider much the sales per employee (Bhuian, 1997), this behaviour of banks will not fetch any good growth in future. Because of economic reasons, the two commercial banks (NCB and Samba Bank) merged to form the most profitable bank in the Middle East (Kane, 2020). The growth in the demand and expectations of banking

(C) Adil Zia. Published in PSU Research Review. Published by Emerald Publishing Limited. This article is published under the Creative Commons Attribution (CC BY 4.0) licence. Anyone may reproduce, distribute, translate and create derivative works of this article (for both commercial and non-commercial purposes), subject to full attribution to the original publication and authors. The full terms of this licence maybe seen at http://creativecommons.org/licences/by/4.0/legalcode 
services has pushed the banks to offer high-quality services. It has been observed in the past that despite the drop of earnings because of low oil prices, the banking sector has performed very well and showed a strong balance sheet in 2015 (Miyajima, 2017), which means that the banking sector in Saudi Arabia has the scope to uplift the whole economy even in the difficult times even when the oil-based earnings drops. Because of the growing need for banking services, this sector has witnessed a boom in the number of branches and services centres.

The increased number of banks has provided customers with a variety to choose from. This has raised the banks to pay due importance to customer satisfaction so as to attract more and more customers and further to make them loyal customers. In some of the research studies, it was observed that the factors such as responsiveness, tangible, reliability, empathy and assurance have a significant influence on service quality (SQ) thereby influencing customer satisfaction (Franklin, 2020; Ishfaq et al., 2020), which is in line with the Saudi Arabian 2030 Vision for economic development. Similarly, in the studies of other Arab countries, the factors identified to have an impact on customer satisfaction and loyalty were identical and had the same impact as in Saudi Arabia (Fida et al., 2020), which indicated that the consumer behaviour of Arab countries is of similar nature. There are no available research studies which attempt to explore the factors that are responsible for the SQ in banks of Saudi Arabia. There exist two gaps in the available literature regarding the SQ in banks in Saudi Arabia. Firstly, the banks are unaware of the factors responsible for customer satisfaction in Saudi Arabia. Secondly, the customers are unaware of their own decision to go to a specific bank.

\section{Background}

The quality of service is an intangible aspect and is considered to be a multi-dimensional facet. This section identifies and delineates the different dimensions of SQ leading to the loyalty of a bank. There have been many types of research related to the measurement of SQ in Saudi Arabia and around the world (Zia and Azam, 2013; Zia and Al Ghaswyneh, 2013; Zia, 2014, 2015, 2019, 2020a; Khatib and Zia, 2016; Zia and Khan, 2018, 2019; Zia and Hashmi, 2019) and it has been found that SQ is related to the concept of satisfaction and leading to the positive attitude thereby resulting in loyalty of customers. The SQ is not only important in banks rather it is also important for the retail stores (Hashmi and Zia, 2020). Services play an important role to get customer loyalty in the banking sector (Khan and Zia, 2019). Customers prefer to use services on mobile phones and try to rate the quality of services leading to customer loyalty (Hossain et al., 2019d, 2020b; Zia, 2020b). All the significant dimensions that may reflect customer's perception about SQ of a bank are deliberated here. Prior to proceeding to elaborate the dimensions of SQ, a conceptual discussion of quality and service, and the SQ significance in relation to banks will be pertinent. Quality is the foremost key prerequisite that influences the creation of perception and level of satisfaction of the customer with regard to any product and service. In terms of bank loyalty intentions, quality plays an important role. The quality of any service is said to be satisfactory only when perceived quality meets the delivered service. Further, this concept of quality can be defined as, "meeting to the need of customer".

\section{Literature review and hypotheses development Quality}

The conceptualization of perception of quality is a subjective matter and this process is dynamic in nature. It is considered that quality emerges out from the gap arising from expected service and the performed service. This gave rise to the equation that $\mathrm{SQ}=\mathrm{P}-\mathrm{E}$ (Lewis and Brooms, 1983). This aspect of quality emerges out of the customers' expectations 
PRR

6,2

92

and disconfirmation paradigm (Oliver et al., 1994). Quality is "A predictable degree of uniformity and dependability to low cost and suited to the market" (Redmond et al., 2008; Hossain et al., 2019a, 2019d). SQ measurement is a challenge now as it was yesterday. The four P's of marketing, which are commonly known as marketing mix, were not applicable to services and therefore, Booms and Bitner (1981) came up with seven P's to define the services marketing mix. Based on the seven P's of the services marketing mix, Parasuraman et al. (1985) developed a scale to measure SQ. This scale came to be known as the SERVQUAL scale. This scale was used by many researchers to measure the SQ but this scale has not been without its criticism. SQ by its nature is an exclusive and abstract concept, which has been defined from different perspective and orientation.

Berry et al. (1985) defined SQ as the gap in the service expectation and service performance. There is a substantial positive effect of all the factors of retail SQ model in Saudi. SQ has a positive and significant impact on customer satisfaction thereby leading to loyalty behaviour (Zia and Khan, 2018, 2019). Three factors of service equality have a noteworthy impact (physical aspect, problem-solving and policy) whereas two factors (reliability and personal interactions) were recognized to be a highly insignificant impact on SQ (Zia and Khan, 2018; Zia and Hashmi, 2019). SQ significantly gives positive influence to customer satisfaction (Santouridis and Trivellas, 2010; Gede Mahatma Yuda Bakti and Sumaedi, 2013). Therefore, to test the impact of various dimensions on the $\mathrm{SQ}$, following review of literature have been presented.

\section{SERVQUAL}

It is an instrument developed to measure the SQ based on the data collected from the respondents who are the users of a product or a service (Parasuraman et al., 1991). This questionnaire contains 22 items grouped in 5 dimensions. Based upon the review of literature, a model was developed to show the relationship among SQ, attitude, satisfaction and loyalty intentions. In Figure 1, a direct relation of loyalty intention, SQ, attitude and satisfaction is depicted.

\section{Tangibles}

Tangibles are the things that are related to the physical aspect of the bank (Siddiqi, 2011; Taap et al., 2011). This aspect tangibilizes the intangible aspect of the SQ of a bank. The physical aspect of the banks makes the first impression on the customers; therefore, these

Figure 1.

Conceptual model for SQ and loyalty relationship

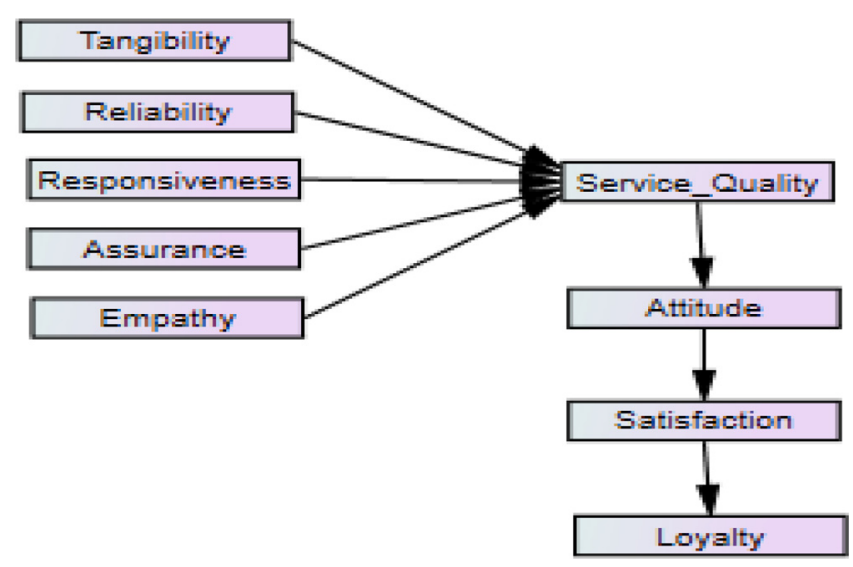


are the first meeting point of customers and the bank. So it acts as a promotional tool for the bank. It includes things such as building, infrastructure, furniture, promotion materials and human resources (employees of the bank). All these things play a vital role in developing a perception in the consumers for the quality of a bank. Hence, the following hypothesis is framed to test whether there is any impact of tangibility aspect on the SQ of a bank:

H1. There is no significant impact of tangibility on the SQ of banks.

\section{Reliability}

Reliability in the banking sector is related to the level of trust that customers keep in the bank. Higher the trust in the bank, higher is the SQ (Siddiqi, 2011). Money is a serious business; therefore, trust is the main driving force for customers to deposit their hard-earned money with the bank. If the bank keeps its promises and do what it claimed to do so will generate reliability in the minds of the customers. The consistency in fulfilling promises over a period of time develops reliability in banks. Therefore, to test the contribution of reliability in developing SQ, the following hypothesis is framed:

H2. There is no significant impact of reliability on the SQ of banks.

\section{Responsiveness}

When the bank provides service according to the requirements of the customers, it leads to the development of a sense of responsiveness. Customers receiving proper and timely solutions to their problems over a period of time led to the image of being responsive. This behaviour of the customer is more prominent in the young generation when they make their choice of a bank on the basis of the level of responsiveness of a bank (Zeng and Wu, 2020). It also includes things such as assisting customers when they enter to the premises of the bank, initiating to offer services and asking to discuss any issues or for any services by the customers that the bank can fulfil. Therefore, to explore and understand the role of responsiveness in developing $\mathrm{SQ}$, the following hypothesis is framed:

H3. There is no significant impact of responsiveness on the SQ of banks.

\section{Assurance}

The concept of the positive declaration by the organisations which is intended to provide confidence is considered assurance (Kumar et al., 2010; Taap et al., 2011). In the banking sector, the factors such as bank staff members, the confidentiality of banking transactions, professional know-how and skills to handle customer complains adequately are included. The young generation of customers expects these skills in the banks' employees (Zia and Khan, 2019; Zeng and $\mathrm{Wu}, 2020)$. Therefore, to test the linkage of assurance and SQ, the following hypothesis is framed:

H4. There is no significant impact of assurance on the SQ of banks.

\section{Empathy}

The SQ characterized by empathy indicates the ability of the bank to understand customers' feelings and the situations they are in for help and assistance. The ability to understand and share the feelings of one another and the associated factors are covered in this dimension. 
PRR

6,2

94

It is observed that many researchers have cited that empathy in customer service leads to a higher level of customer satisfaction (Dawson et al., 1992; McBane, 1995; Derksen et al., 2013) The attribute of empathy demands a feeling in the attitude of staff to give personal attention and care to customers. Moreover, it also encompasses the level of individual interaction paid by the staff to the customers for their inquiries and grievances. Therefore, to test the impact and the relationship of empathy to the SQ, the following hypothesis has been framed:

H5. There is no significant impact of empathy on the SQ of banks.

\section{Satisfaction}

It has been observed that many researchers have found a significant relationship between the satisfaction level and the SQ (Parasuraman et al., 1991; Ozioma and Marcus, 2020; Zeng and $\mathrm{Wu}, 2020)$. Although, it has been observed that there is a mediating role of satisfaction in loyalty formation (Caceres and Paparoidamis, 2007; Zeng and Wu, 2020). The studies in banks, the hospitality industry and retail services have highlighted that higher levels of SQ lead to a higher leave of satisfaction which further leads customers to form a positive attitude. Therefore, to test this relationship and the impact of satisfaction, the following hypothesis has been framed:

H6. There is no significant impact of SQ on the satisfaction of the customers.

\section{Attitude}

It is considered to be a psychological factor that shows the state of mind of a person, it may be positive, negative or neutral. The attitude of a person towards a service or product leads to its liking or disliking (Fishbein and Ajzen, 1975). Further, in many research studies, it was found that attitude acts as a mediating factor for the SQ (Suh and Pedersen, 2010). Attitudes are formed over a period of time by the experiences and the use of things that they come in contact (Allport, 1935; Hossain et al., 2019b, 2020b). Therefore, to test the impact of satisfaction on the attitude of customers, the following hypothesis has been formed:

H7. There is no significant impact of satisfaction on the attitudes of customers.

\section{Loyalty}

Customer loyalty is the thing that every organization asks for. It has been observed from past studies that loyal customers are more profitable than new customers. Further, it is also observed that the cost of acquiring new customers is way more difficult than keeping the old customer with the organization (Oliver, 1999). Therefore, repeat customers are always liked by retailers and it represents the strength of individual attitude towards a product or a service (Dick and Basu, 1994). This concept of loyalty represents a paradox, which means that an attitude-based phenomenon is influenced by loyalty programs (Kumar et al., 2010). So based on these arguments, the following hypothesis has been formulated to test the impact of attitude on consumer loyalty:

H8. There is no significant impact of customer attitude on customer loyalty. 
- To explore the factors contributing to the SQ of a bank.

- To find the impact of five factors (tangibility, reliability, responsiveness, assurance and empathy) on SQ of a bank.

- Establish the relationship of SQ, satisfaction, attitude and loyalty of a bank.

\section{Methodology}

This study was conducted to explore the factors responsible for SQ and loyalty intentions in banks of Saudi Arabia (Albaha region). The population is defined as active bank account holders in and around the Albaha region of Saudi Arabia. Responses were collected from the customers who filled the questionnaire after finishing their tasks in the bank or when they were looking for their turn to get served in the bank. For this study, the modified SERVQUEL questionnaire (Parasuraman et al., 1988) was used to collect primary data through a convenience sampling technique (Appendix). This is a well-developed scale already existing to measure the SQ used by many researchers in similar studies in Arab and other countries (Zia, 2015; Hossain et al., 2019d, 2020a, 2019b, 2019c, 2020b; Zia and Khan, 2019). Five banks were selected from the Albaha region to collect the data from 1,400 respondents. Out of 1,400 respondents, 1,097 questionnaires were received making a response rate of approximately $66.33 \%$ out of which 432 completely filled questionnaires were finally considered for the study. The banks were from different locations of Albaha region and most were from Al-Aquiq, Albaha and Buljurshihe. The banks selected for the study and the numbers of respondent details and statistics are given in Tables 1 and 2. It took nearly 12 weeks to collect this data from November 2019 to January 2020.

As the SERVQUEL scale has been tried and confirmed through various retail formats, regions and countries and it provides authenticated results, therefore, this scale was adopted for the study in the Saudi Arabian context. SERVQUEL scale was used to collect data from all the customers irrespective of their nationality. This questionnaire collected the data

\begin{tabular}{llc}
\hline S. No. & Name of bank & No. questionnaires received \\
\hline 1 & Al Rajhi Bank & 215 \\
2 & Al Bilad Bank & 196 \\
3 & Samba Bank & 170 \\
4 & Riyadh Bank & 185 \\
5 & Al Ahli Bank & 166 \\
\hline
\end{tabular}


PRR

6,2

96

using a five-point Likert scale which ranges from strongly agree to strongly disagree. In this questionnaire, the respondents were asked to choose only one option based upon the best experience.

\section{Analysis and findings}

The factors of SQ of a bank were identified using SQ scale (SERVQUEL). The validity of this questionnaire for this study was checked using factor analysis using Cronbach's alpha values. Table 3 shows the overall value of Cronbach's alpha for all the 30 items of the scale together followed by the individual Cronbach's alpha value calculation for each variable. The value of Cronbach's alpha for all the items together is 0.985 which shows high reliability of the scale. Subsequently, it was found that the value is well above 0.7 ; hence, it is valid to use this scale for this study. The Cronbach's alpha value for the data is shown in Table 3. It is found that for all the factors, the Cronbach's alpha values were above 0.6 except for satisfaction. As overall Cronbach's alpha value is in the acceptable limits, so the scale is adapted for further analysis.

Table 4 shows two tests that indicate the suitability of the data for structure detection. The statistic that indicates the proportion of variance in the variables that might be caused by underlying factors is the Kaiser-Meyer-Olkin (KMO) measure of sampling adequacy and the values obtained are high values (close to 1.0); this commonly indicates that factor analysis may be useful for the data used for this study. It is further an established fact that the values less than 0.50 indicated the results of the factor analysis that may not be very useful. In this case, the value is 0.851 , which indicates the applicability of factor analysis.

Bartlett's test of sphericity checks the hypothesis that the correlation matrix is an identity matrix, which would indicate that the variables are unrelated and therefore unsuitable for structure detection. The values less than 0.05 are considered to be small values and it is considered to be significant at which the factor analysis may be useful with the data. The value of 0.000 indicates high significance; therefore, factor analysis is indicated for this data in the present study.

\begin{tabular}{|c|c|c|c|c|c|}
\hline \multirow[b]{2}{*}{$\begin{array}{l}\text { Table } 3 \text {. } \\
\text { Reliability of selected } \\
\text { factors }\end{array}$} & \multicolumn{4}{|c|}{$\begin{array}{l}\text { Reliability of overall scale Cronbach's alpha } \\
0.985\end{array}$} & $\begin{array}{l}\text { No. of items } \\
33\end{array}$ \\
\hline & $\begin{array}{l}\text { S. No. } \\
1 \\
2 \\
3 \\
4 \\
5 \\
6 \\
7 \\
8\end{array}$ & $\begin{array}{l}\text { Dimensions } \\
\text { D1 } \\
\text { D2 } \\
\text { D3 } \\
\text { D4 } \\
\text { D5 } \\
\text { D6 } \\
\text { D7 } \\
\text { D8 }\end{array}$ & $\begin{array}{l}\text { Cronbach's alpha } \\
\text { Tangibility } \\
\text { Reliability } \\
\text { Responsiveness } \\
\text { Assurance } \\
\text { Empathy } \\
\text { Attitude } \\
\text { Satisfaction } \\
\text { Loyalty }\end{array}$ & $\begin{array}{l}\text { Value } \\
0.782 \\
0.861 \\
0.895 \\
0.994 \\
0.622 \\
0.692 \\
0.591 \\
0.714\end{array}$ & $\begin{array}{c}\text { No. of items } \\
4 \\
5 \\
4 \\
4 \\
4 \\
4 \\
4 \\
3\end{array}$ \\
\hline & $\mathrm{KMO} \mathrm{r}$ & sampling adec & & & 0.851 \\
\hline $\begin{array}{l}\text { Table } 4 \text {. } \\
\text { KMO and Bartlett's } \\
\text { test }\end{array}$ & $\begin{array}{l}\text { Bartlet } \\
\text { Appro } \\
\text { Df } \\
\text { Sig. }\end{array}$ & hericity & & & $\begin{array}{c}5295.432 \\
21 \\
0.000\end{array}$ \\
\hline
\end{tabular}


Factor analysis is a method of data reduction (Table 5) and it does this by seeking underlying unobservable (latent) variables that are reflected in the observed variables (manifest variables). The SQ is the latent variable whereas the five dimensions are the observed variables. These five factors explain the variance in SQ up to $92.88 \%$.

The first main objective of this research was to explore the factors related to the customer loyalty of banks in Albaha. To this aim, thorough literature was reviewed and the eight factors (assurance, responsiveness, reliability, tangibility, empathy, SQ, satisfaction and attitude) were found to have an impact on loyalty. Further, a relationship model was developed using structural equation modelling (SEM) to measure the impact of seven factors of the loyalty intentions for bank customers. Figures 2 and 3 show the output of standardized estimates. It shows that reliability has the maximum impact on the SQ (0.69). This output shows the importance of reliability of services in determining customer loyalty for a bank. On the other hand, responsiveness has scored the lowest value.

The summary results of multiple linear regression analysis (Table 6) and overall fit statistics shows that the adjusted $R^{2}$ of the model is 0.946 with the $R^{2}=0.947$. This means that the linear regression explains $92.88 \%$ of the variance in the data. This indicates that $92.884 \%$ of the variance in the dependent variable (loyalty) can be explained by the independent variables.

The multiple linear regression estimates (Table 7), including the intercept and the significance levels, shows that the enter method of multiple linear regression analysis was

\begin{tabular}{|c|c|c|c|c|}
\hline Component & Total & $\begin{array}{l}\text { Initial eigenvalues } \\
\% \text { of variance }\end{array}$ & Cumulative (\%) & \\
\hline 1 & 32.329 & 79.211 & 79.211 & \\
\hline 2 & 7.314 & 9.321 & 88.532 & \\
\hline 3 & 0.923 & 2.246 & 90.778 & Table 5. \\
\hline 4 & 0.231 & 1.294 & 92.072 & Factor analysis for \\
\hline 5 & 0.221 & 0.812 & 92.884 & $\mathrm{SQ}$ \\
\hline
\end{tabular}



Figure 2. Unstandardized 


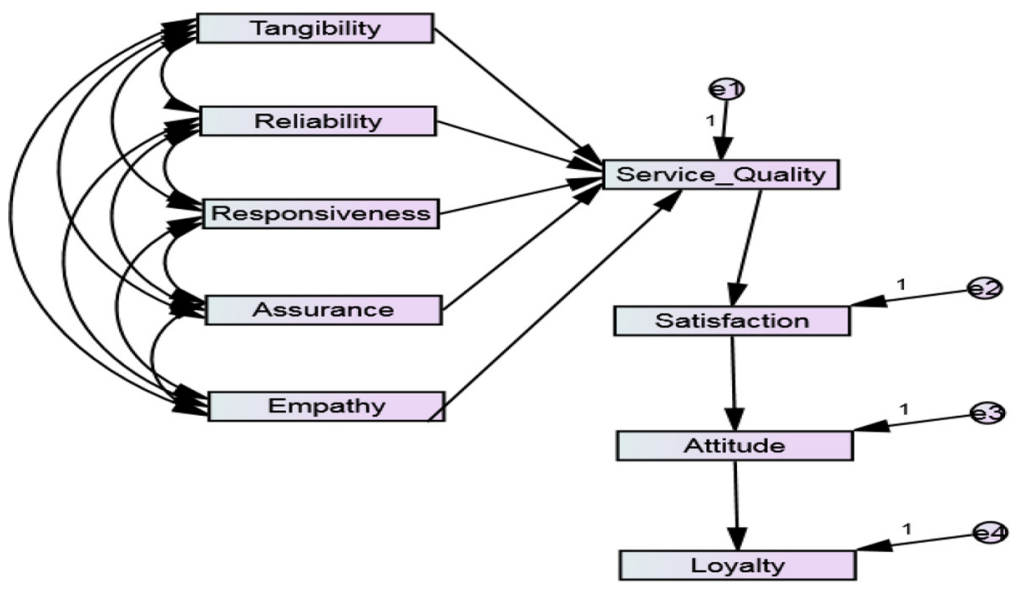

Figure 3.

Standardized

\begin{tabular}{ccccc}
\hline Model & $R$ & $R^{2}$ & Adjusted $R^{2}$ & Standard error of the estimate \\
\hline 1 & $0.973^{\mathrm{a}}$ & 0.947 & 0.946 & 0.26287
\end{tabular}

Table 6.

Model summary

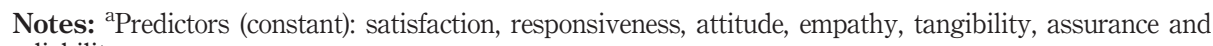
reliability

Table 7.

Coefficients $^{\mathrm{a}}$

\begin{tabular}{llccccr}
\hline & \multicolumn{5}{c}{$\begin{array}{c}\text { Standardized } \\
\text { Coefficients } \\
\text { Model }\end{array}$} & \multicolumn{2}{c}{ Unstandardized coefficients } & Beta & $t$ & Sig. \\
\hline $1 \quad$ (Constant) & -0.696 & 0.096 & & -7.263 & 0.000 \\
& Tangibility & 0.069 & 0.055 & 0.069 & 1.260 & 0.209 \\
& Reliability & 0.442 & 0.122 & 0.363 & 3.620 & 0.000 \\
& Responsiveness & 0.002 & 0.016 & 0.002 & 0.138 & 0.890 \\
Assurance & 0.214 & 0.059 & 0.203 & 3.641 & 0.000 \\
& Empathy & 0.034 & 0.059 & 0.026 & 0.580 & 0.562 \\
& Attitude & 0.043 & 0.013 & 0.042 & 3.264 & 0.001 \\
& Satisfaction & 0.372 & 0.116 & 0.312 & 3.211 & 0.001
\end{tabular}

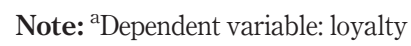

adapted. It was found that this model has a significant intercept at $p=0.000$ and highly insignificant tangibility, responsiveness and empathy.

The first value in this model is the value of "constant", which is the predicted value of loyalty when all other independent variables are zero. The regression that can be formed for this analysis in the equation is $\mathrm{Sq}(\mathrm{Y})=\alpha+\beta 1 x 1+\beta 2 x 2+\beta 3 x 3+\beta 4 x 4+\beta 5 x 5+\beta 6 x 6+\beta 7 x 7$.

$\mathrm{Sq}=$ loyalty; and

$\alpha=$ intercept value (constant) and $\beta 1, \beta 2, \beta 3, \beta 4, \beta 5, \beta 6$ and $\beta 7$ are the $\beta$ values. 


$$
\begin{aligned}
\mathrm{Sq}(\mathrm{Y})= & \operatorname{constant}(\alpha)+\beta 1 \text { (tangibility) }+\beta 2 \text { (reliability) }+\beta 3 \text { (responsiveness) } \\
& +\beta 4 \text { (assurance) }+\beta 5 \text { (empathy) }+\beta 6 \text { (attitude) }+\beta 7 \text { (satisfaction) } \\
\mathrm{Sq}(\mathrm{Y})= & -0.696(\alpha)+0.069 \text { (tangibility) }+0.442 \text { (reliability) }+0.002 \text { (responsiveness) } \\
& +0.214 \text { (assurance) }+0.034(\text { empathy })+0.043 \text { (attitude) }+0.372 \text { (satisfaction) }
\end{aligned}
$$

Regression weight (Table 8) shows that assurance and reliability has a positive significant effect on SQ whereas SQ has a positive significant effect on satisfaction thereby satisfaction has a positive significant effect on attitude and attitude has a positive significant effect on loyalty. The effect of SQ is flowing through satisfaction and attitude to the loyalty of the customers in a bank.

\section{Discussions}

This study starts with the assumption of the relationship among the loyalty and the predictor variables (tangibility, reliability, responsiveness, assurance, empathy, attitude and satisfaction). The null hypothesis states that there is no probability of a linear relationship between a dependent (loyalty) and predictor variables. As this hypothesis is rejected, therefore it can be said that all the factors are contributing to the determination of loyalty. Consequently, these factors are important for the sake of developing and maintaining customer loyalty for banks of Saudi Arabia.

Out of the seven variables, four variables have significant impact whereas three variables were found to have an insignificant impact on loyalty. These results are similar in both multiple regressions and in SEM (see Tables 8 and 9). In both SEM and multiple regressions, same factors are significant. The SEM and multiple regression were used to develop more authentic results related to the factors affecting SQ of a bank in Saudi Arabia.

\begin{tabular}{lllcrrrr}
\hline Factor & & & Estimate & S.E. & C.R. & $p$ & Label \\
\hline Service_Quality & $<-$ & Assurance & 0.258 & 0.059 & 4.394 & $* * *$ \\
Service_Quality & $<-$ & Responsiveness & 0.024 & 0.017 & 1.382 & 0.167 \\
Service_Quality & $<-$ & Reliability & 0.837 & 0.036 & 23.304 & $* * *$ \\
Service_Quality & $<-$ & Tangibility & 0.028 & 0.025 & 1.127 & 0.260 \\
Service_Quality & $<-$ & Empathy & 0.056 & 0.056 & 0.988 & 0.323 \\
Satisfaction & $<-$ & Service_Quality & 0.793 & 0.029 & 26.917 & $* * *$ \\
Attitude & $<-$ & Satisfaction & 0.848 & 0.024 & 35.788 & **** \\
Loyalty & $<-$ & Attitude & 0.895 & 0.027 & 33.383 & $* * *$
\end{tabular}

Table 8.

\begin{tabular}{|c|c|c|c|c|c|c|c|}
\hline S. No. & Factors & $\begin{array}{c}\text { Regression } \\
\text { values }\end{array}$ & $p$-value & Impact & Hypothesis & Test result & \\
\hline 1 & Tangibility & 0.028 & 0.209 & Insignificant & $H 1$ & Rejected & \\
\hline 2 & Reliability & 0.837 & 0.000 & Significant & $H 2$ & Accepted & \\
\hline 3 & Responsiveness & 0.024 & 0.890 & Insignificant & $H 3$ & Rejected & \\
\hline 4 & Assurance & 0.258 & 0.000 & Significant & $H 4$ & Accepted & \\
\hline 5 & Empathy & 0.056 & 0.562 & Insignificant & H5 & Rejected & Table 9. \\
\hline 6 & Satisfaction & 0.848 & 0.001 & Significant & $H 7$ & Accepted & Summary results of \\
\hline 7 & Attitude & 0.895 & 0.001 & Significant & $H 6$ & Accepted & hypothesis testing \\
\hline
\end{tabular}

Regression weights: (group number 1default model) 
PRR

6,2

Overall, the $R^{2}$ value of 0.947 shows that $94.7 \%$ of the data fits in the regression model. As this value is above 0.9 , therefore it shows an excellent fit for the model. The R-value of 0.973 is very high to show the correlation among the predictor variable and the observed variable. This is showing a very high correlation because this topic of loyalty is well researched and all the items were included after proper consideration. The standardized beta coefficient value for reliability is highest (0.36) and significant (Table 7), which shows that the maximum important variable for the determination of loyalty is reliability. Throughout the literature, reliability factor was found to have a higher impact on loyalty across the cultures around the world. Tangibility, responsiveness and empathy were found to be insignificant. This is because in the banking sector, these factors might not have an active role to play in the formation of loyal customers.

The linear relationship was predicted in the model and the results suggest that SQ does not directly contribute to the customer loyalty and rather there is a stepwise process. Firstly, SQ determines satisfaction, which means that if the customers are satisfied then only they will consider SQ up to their expected level. Further, the satisfaction level changes the attitude of customers, which is the next level to reach customer loyalty. After attaining favourable attitude, the customer becomes loyal. Therefore, it was found that it is a stepwise process where a customer develops loyalty after three stages. The first stage is SQ followed by satisfaction which develops attitude in favour of a bank resulting in the customer loyalty.

\section{Conclusions}

Seven hypotheses explore the relationship between dependent and independent factors. Four hypotheses were accepted whereas three hypotheses were rejected. Moreover, it was found that all factors have a positive impact on the SQ of the banks in Saudi Arabia. This study highlights the importance of reliability in developing customer loyalty intention in Saudi Arabia. So it can be understood that Saudi Arabian customers in Albaha region develop loyalty intention if they experience the reliability of the services.

Another objective of this study was to investigate the impact of factors responsible for customer loyalty intention in banks of Albaha region, Saudi Arabia. It was found that reliability has the highest impact whereas responsiveness has the lowest impact (Table 9) on SQ of the banks in Saudi Arabia.

\section{Implications of the study}

Based on this study, it can be recommended to the banks in Albaha region in Saudi Arabia that if they want to increase the customers' loyalty, they have to give due importance to reliability followed by the other factors. This study will help banks to explore the factors that are responsible for SQ and in understanding the customer's behaviour related to banks in the Albaha. The findings of the study will benefit banks in improving satisfaction and loyalty level among customers of Albaha region in Saudi Arabia.

\section{Limitations}

In this study, only a limited number of customers were considered for analysis. This study could be conducted for a larger group of customers and by further dividing the customers into subgroups based on demographic segmentation. Secondly, this study does not test the direct relationship of SQ with the attitude and loyalty, therefore it could be another area of investigation. 


\section{References}

Allport, G. (1935), Attitudes: A Handbook of Social Psychology, Clark University Press.

Asubonteng, P., Mccleary, K.J. and Swan, J.E. (1996), "SERVQUAL revisited: a critical review of service quality”, Journal of Services Marketing, Vol. 10 No. 6, pp. 62-81, doi: 10.1108/08876049610148602.

Berry, L.L., Zeithaml, V.A. and Parasuraman, A. (1985), "Quality counts in services, too", Business Horizons, Vol. 28 No. 3, pp. 44-52, doi: 10.1016/0007-6813(85)90008-4.

Bhuian, S.N. (1997), "Exploring market orientation in banks: an empirical examination in Saudi Arabia", Journal of Services Marketing, Vol. 11 No. 5, pp. 317-328, doi: 10.1108/ 08876049710176006.

Booms, B.H. and Bitner, M.J. (1981), "Marketing strategies and organization structure for service firms", in Donelly, J.H. and George, W.R. (Eds), Marketing of Services.

Caceres, R.C. and Paparoidamis, N.G. (2007), "Service quality, relationship satisfaction, trust, commitment and business-to-business loyalty", European Journal of Marketing, Vol. 41 Nos 7/8, pp. 836-867, doi: 10.1108/03090560710752429.

Dawson, L.E., Soper, B. and Pettijohn, C.E. (1992), "The effects of empathy on salesperson effectiveness", Psychology and Marketing, Vol. 9 No. 4, pp. 297-310, doi: 10.1002/mar.4220090404.

Derksen, F., Bensing, J. and Lagro-Janssen, A. (2013), "Effectiveness of empathy in general practice: a systematic review", British Journal of General Practice, Vol. 63 No. 606, doi: 10.3399/ bjgp13X660814.

Dick, A.S. and Basu, K. (1994), "Customer loyalty: toward an integrated conceptual framework”, Journal of the Academy of Marketing Science, Vol. 22 No. 2, pp. 99-113, doi: 10.1177/0092070394222001.

Fida, B.A., et al. (2020), "Impact of service quality on customer loyalty and customer satisfaction in Islamic banks in the sultanate of Oman", SAGE Open, Vol. 10 No. 2, doi: 10.1177/ 2158244020919517.

Fishbein, M. and Ajzen, I. (1975), "Chapter 2. Theories of attitude (EVT)”, Belief, Attitude, Intention, and Behavior, an Introduction to Theory and Research, pp. 21-52.

Franklin, U.E. (2020), "The impact of service quality on satisfaction of bank customers: the Saudi Arabian case the impact of service quality on satisfaction of bank customers: the Saudi Arabian case", International Journal of Academic Research in Business and Social Sciences, Vol. 1 No. 8, pp. 763-771, doi: 10.6007/IJARBSS/v10-i8/7624.

Gede Mahatma Yuda Bakti, I. and Sumaedi, S. (2013), "An analysis of library customer loyalty: the role of service quality and customer satisfaction, a case study in Indonesia", Library Management, Vol. 34 Nos 6/7, pp. 397-414, doi: 10.1108/LM-05-2012-0025.

Hashmi, A.R. and Zia, A. (2020), "customer relationship towards boundary spanner in-store (bakhala) : a Saudi perspective”, Academy of Marketing Studies Journal, Vol. 24 No. 2, pp. 1-8, available at: www.abacademies.org/journals/academy-of-marketing-studies-journal-inpress.html

Hossain, S.F.A., Shan, X. and Nurunnabi, M. (2019a), "Is M-learning a challenge? Students attitudes toward the sustainable learning and performance", International Journal of e-Collaboration, Vol. 15 No. 1, pp. 21-37, doi: 10.4018/IJeC.2019010102.

Hossain, S.F.A., Shan, X., Musa, M. and Rahman, P. (2019b), "Social media and increased venture creation tendency with innovative ideas: the case of female students in Asia", Handbook of Research on Managerial Practices and Disruptive Innovation in Asia, doi: 10.4018/978-1-79980357-7.ch011.

Hossain, S.F.A., Xi, Z., Nurunnabi, M. and Anwar, B. (2019c), "Sustainable academic performance in higher education: a mixed method approach", Interactive Learning Environments, doi: 10.1080/ 10494820.2019.1680392.

Hossain, S.F.A., Nurunnabi, M., Hussain, K., Saha, S.K. and Wang, S. (2019d), "Effects of varietyseeking intention by mobile phone usage on university students' academic performance", Cogent Education, Vol. 6 No. 1, pp. 1-18, doi: 10.1080/2331186X.2019.1574692. 
PRR

6,2

Hossain, S.F.A., Nurunnabi, M., Hussain, K. and Shan, X. (2020a), "Smartphone-based m-shopping behavior and innovative entrepreneurial tendency among women in emerging Asia", International Journal of Gender and Entrepreneurship, Vol. 12 No. 2, pp. 173-189, doi: 10.1108/IJGE-03-2019-0054.

Hossain, S.F.A., Xi, Z., Nurunnabi, M. and Hussain, K. (2020b), "Ubiquitous role of social networking in driving M-Commerce: evaluating the use of mobile phones for online shopping and payment in the context of trust", SAGE Open, Vol. 10 No. 3, pp. 1-11, doi: 10.1177/2158244020939536.

Ishfaq, M., Al Hajieh, H. and Alharthi, M. (2020), "Quality determination of the Saudi retail banking system and the challenges of vision 2030", International Journal of Financial Studies, Vol. 8 No. 3, pp. 1-19, doi: 10.3390/ijfs8030040.

Kane, F. (2020), "NCB and samba announce merger to form Saudi Arabia's $\$ 220$ billion mega- bank, Arab news", available at: www.arabnews.com/node/1747376/business-economy

Khan, A.A. and Zia, A. (2019), "Market volatility of banking stock return vis-à-vis banks merger: an application of Garch model”, Management Science Letters, Vol. 9 No. 5, pp. 1-10, doi: 10.5267/j. ms1.2019.2.008.

Khatib, F.S. and Zia, A. (2016), "Impact of service quality on customer satisfaction - an imperial study of mobily in Saudi Arabia”, European Journal of Social Sciences, Vol. 51 No. 4, pp. 451-460, available at: www.europeanjournalofsocialsciences.com/issues/EJSS_51_4.html

Kumar, M., Kee, F.T. and Charles, V. (2010), "Comparative evaluation of critical factors in delivering service quality of banks: an application of dominance analysis in modified SERVQUAL model", International Journal of Quality and Reliability Management, doi: 10.1108/02656711011023320.

Lewis, R.C. and Brooms, B.H. (1983), “The marketing aspects of service quality”, Emerging Perspectives on Services Marketing, Vol. 65 No. 4, pp. 99-107, doi: 10.1108/03090560210437389.

McBane, D.A. (1995), "Empathy and the salesperson: a multidimensional perspective", Psychology and Marketing, doi: 10.1002/mar.4220120409.

Miyajima, K. (2017), "What influences bank lending in Saudi Arabia?”, IMF Working Papers, Vol. 17 No. 31, p. 1, doi: 10.5089/9781475578669.001.

Oliver, R.L. (1999), "Whence consumer loyalty?", Journal of Marketing, Vol. 63 No. 4_suppl1, doi: 10.2307/1252099.

Oliver, R.L., Balakrishnan, P.V.S. and Barry, B. (1994), "Outcome satisfaction in negotiation: a test of expectancy disconfirmation", Organizational Behavior and Human Decision Processes, Vol. 60 No. 2, doi: 10.1006/obhd.1994.1083.

Ozioma, N.D. and Marcus, A.O. (2020), "Marketing public relations and consumer patronage of bank", Vol. 3 No. 1, pp. 1-19.

Parasuraman, A., Zeithaml, V.A. and Berry, L.L. (1985), "A conceptual model of service quality and its implications for future research", Journal of Marketing, Vol. 49 No. 4, doi: 10.2307/1251430.

Parasuraman, A., Zeithaml, V.A. and Berry, L.L. (1988), "SERQUAL: a multiple-item scale for measuring consumer perceptions of service quality", Journal of Retailing, doi: 10.1016/S01482963(99)00084-3.

Parasuraman, A.A., Zeithaml, V.A. and Berry, L.L. (1991), "Refinement and reassessment of the SERVQUAL instrument”, Journal of Retailing.

Redmond, R., et al. (2008), "Quality in higher education: the contribution of Edward Deming's principles", International Journal of Educational Management, Vol. 22 No. 5, doi: 10.1108/ 09513540810883168.

Santouridis, I. and Trivellas, P. (2010), "Investigating the impact of service quality and customer satisfaction on customer loyalty in mobile telephony in Greece", TQM Journal, doi: 10.1108/ 17542731011035550 .

Siddiqi, K.O. (2011), "Interrelations between service quality attributes, customer satisfaction and customer loyalty in the retail banking sector in Bangladesh", International Journal of Business and Management, Vol. 6 No. 3, doi: 10.5539/ijbm.v6n3p12. 
Suh, Y.I. and Pedersen, P. (2010), "Participants' service quality perceptions of fantasy sports websites: the relationship between service quality, customer satisfaction, attitude, and actual usage", Sport Marketing Quarterly.

Taap, M.A., et al. (2011), "Measuring service quality of conventional and Islamic banks: a comparative analysis", International Journal of Quality and Reliability Management, doi: 10.1108/02656711111162505.

Zeng, L. and Wu, N. (2020), "Research on the service quality of personal online banking from the perspective of the new generation", Vol. 110 No. Emle, pp. 741-745, doi: 10.2991/aebmr. k.191225.136.

Zia, A. (2014), "Impact of shopping experience on consumer loyalty: an empirical study of organized retailers", SOSIOHUMANIKA: Jurnal Pendidikan Sains Sosial Dan Kemanusiaan, Vol. 7 No. 1, pp. 137-144, available at: http://journals.mindamas.com/index.php/sosiohumanika/article/view/ 506

Zia, A. (2015), "Transformational leadership a study of banking sector in Saudi Arabia”, Global Journal of Management and Business Research, Vol. 15 No. January, pp. 19-26, available at: https:// globaljournals.org/GJMBR_Volume15/3-Transformational-Leadership.pdf

Zia, A. (2019), "Store brands purchase intentions: an empirical investigation of super markets in Al-Baha, Saudi Arabia", Shanlax International Journal of Commerce. Shanlax International Journal of Commerce, Vol. 7 No. S1, pp. 96-101, doi: 10.5281/zenodo.3451621.

Zia, A. (2020a), "Assessing the service quality of department store using RSQS an empirical study of Albaha region, Saudi Arabia", Rajagiri Management Journal, Vol. 14 No. 1, pp. 19-33, doi: 10.1108/ramj-11-2019-0023.

Zia, A. (2020b), "Exploring factors influencing online classes due to social distancing in COVID-19 pandemic: a business students perspective", International Journal of Information and Learning Technology, Ahead-of-p(Ahead-of-Print), doi: 10.1108/IJILT-05-2020-0089.

Zia, A. and Al Ghaswyneh, O.F.M. (2013), "Impact of shopping experience on consumer loyalty: an empirical study of organized retailers", ResearchersWorld -Journal of Arts, Science and Commerce, Vol. 4 No. 3, pp. 132-138.

Zia, A. and Azam, K.M. (2013), "Unorganized retail shopping experience in India: an empirical investigation", Pacific Business Review International, Vol. 5 No. 7, pp. 7-16, available at: www. pbr.co.in/2013/2013_month/January/2.pdf

Zia, A. and Hashmi, A.R. (2019), "Exploring the factors affecting service quality of Zain mobile subscribers in Albaha, Saudi Arabia", International Journal of Innovative Technology and Exploring Engineering, Vol. 8 No. 11, pp. 2400-2405, doi: 10.35940/ijitee.J9934.0981119.

Zia, A. and Khan, A.A. (2018), "Measuring service quality of apparel stores using RSQS an empirical study of Albaha region Saudi Arabia”, Research Review International Journal of Multidisciplinary, Vol. 3 No. 12, pp. 58-65, available at: www.rrjournals.com

Zia, A. and Khan, A.A. (2019), "Exploring factors for patronage intentions in Saudi banks: an empirical study of AlBaha province, Saudi Arabia”, International Journal of Research and Review, Vol. 6 No. 1, pp. 346-358.

\section{Web source}

SAMA (2020), available at: https://corporatefinanceinstitute.com/resources/careers/companies/banks-insaudi-arabia/

\section{Further reading}

Grönroos, C. (1983), "Innovative marketing strategies and organization structures for service firms", Emerging Perspectives on Services Marketing, pp. 9-21. 


\section{PRR}

6,2

104

\title{
Appendix
}

\begin{tabular}{lll}
\hline & & \\
Dimensions & Statements of the questionnaire & Items of the \\
\hline Tangibility & Your bank has the modern looking equipment & questionnaire \\
& Your bank's physical features are visually appealing & Q1 \\
& Your bank's employees are neat in appearance & Q2 \\
& Your bank's materials associated with the services (such as pamphlets or & Q3 \\
& statements) are usually appealing at the bank & \\
Reliability & When your bank promises to do something by certain time, it does so & Q5 \\
& Your bank performs the service right at the first time & Q6 \\
& Your bank provides its services at the right time, it promises to do so & Q7 \\
& Your bank tells the exact time the service will be performed & Q8 \\
Responsiveness & Your bank gives prompt service to the customers & Q9 \\
& Your bank always shows willingness to help customers & Q10 \\
& Your bank responds to the customer requests despite being busy & Q11 \\
Assurance & The behaviour of employees of your bank fills confidence in you & Q12 \\
& You feel safe in your transaction with your bank & Q13 \\
& Employees of your bank are polite with you & Q14 \\
& Employees of your bank have the knowledge to answer your questions & Q15 \\
Empathy & Your bank gives individual attention & Q16 \\
& Your bank deal with customers with care & Q17 \\
& Your bank keeps the customers interest at the centre & Q18 \\
& Your bank understands the specific needs of the customers & Q19 \\
Attitude & Your bank has a favourable attitude towards you & Q20 \\
& Your bank has a good attitude towards you & Q21 \\
& Your bank has a positive attitude towards you & Q22 \\
& Your bank has a present attitude towards you & Q23 \\
Loyalty & I believe that I am satisfied with the bank's service & Q24 \\
& Overall, I am pleased with the bank's service & Q25 \\
& Using the services from my bank is a present experience & Q26 \\
& My feelings towards the bank are satisfactory & Q27 \\
& Next time anyone needs banking service, I will recommend my bank & Q28 \\
& I do not regret being a loyal customer & Q29 \\
& I will continue to be loyal customer of my bank & Q30
\end{tabular}

Sources: Parasuraman et al. (1991) and Asubonteng et al. (1996)

\begin{abstract}
About the author
Dr Adil Zia is a Professor at the Marketing College of Business Administration, Albaha University, Saudi Arabia. $\mathrm{He}$ is $\mathrm{PhD}$ in Marketing from Aligarh Muslim University, India. He has more than 13 years of teaching and research experience in India and Saudi Arabia and published research papers in Scopus, ABDC, Emerald, Web of Science and other reputed indexed journals. His areas of interest include, research methods, marketing management, services marketing, retail management and consumer behaviour. Adil Zia can be contacted at: dradilzia@gmail.com
\end{abstract}

For instructions on how to order reprints of this article, please visit our website: www.emeraldgrouppublishing.com/licensing/reprints.htm Or contact us for further details: permissions@emeraldinsight.com 